\title{
ISOLASI, EFEKTIVITAS, DAN KARAKTERISASI BAKTERIOFAG LITIK Salmonella enterica SEBAGAI BIOKONTROL PENYAKIT GASTROENTERITIS
}

\section{ISOLATION, EFFECTIVENESS, AND CHARACTERIZATION OF Salmonella enterica LYTIC BACTERIOPHAGE FOR BIOCONTROL OF GASTROENTHERITIS}

\author{
Debi Arivo $^{1 *}$, Tessa Sjahriani ${ }^{2}$ \\ ${ }^{1}$ Departemen Mikrobiologi, Fakultas Kedokteran Universitas Malahayati, \\ Jl. Pramuka No.27, Bandar Lampung, Indonesia \\ ${ }^{2}$ Departemen Ilmu Kesehatan Masyarakat, Fakultas Kedokteran Universitas Malahayati, \\ Jl. Pramuka No.27, Bandar Lampung, Indonesia
}

\begin{abstract}
ABSTRAK
Salmonella enterica merupakan salah satu bakteri patogen penyebab gastroenteritis yang ditransmisikan melalui air dan makanan terkontaminasi yang sering terjadi pada negara berkembang. Beberapa strain Salmonella enterica multi-resisten terhadap berbagai antibiotika. Bakteriofag litik pada famili Siphoviridae dapat menjadi solusi alternatif dalam mengurangi kejadian gastroenteritis oleh Salmonella enterica. Tujuan penelitian ini adalah untuk mengisolasi, mengetahui kemampuan bakteriofag litik Lytic Bacteriophage 1 (LB1) dalam melisis inangnya yaitu Salmonella enterica penyebab gastroenteritis, serta mengetahui karakterisasi bakteriofag litik LB 1 sebagai biokontrol penyakit gastroenteritis. Bakteriofag litik diisolasi dari pembuangan limbah domestik menggunakan teknik double layer plaque. Bakteriofag litik diidentifikasi berdasarkan morfologi plak, struktur litik, inang, aktivitas lisis sel bakteri Salmonella enterica, stabilitas dalam kondisi buffer yang berbeda dan karakterisasi protein. Bakteriofag litik LB1 hanya menginfeksi sel Salmonella enterica. Hasil pemeriksaan dengan menggunakan Transmission Electron Microscope (TEM), bakteriofag litik LB1 termasuk ke dalam famili Siphoviridae. Morfologi kepala hexagonal-icosahedral berdiameter 72,7 nm, dengan ekor non-kontraktil berdiameter 17,3 nm dan panjang $100 \mathrm{~nm}$. Bakteriofag litik LB1 memiliki stabilitas terbaik dalam buffer Ringers suhu $4{ }^{\circ} \mathrm{C}$ yang ditunjukkan dengan penurunan plak sebesar $28 \%$ setelah 3 minggu penyimpanan. Hasil pengujian efektivitas menunjukkan bahwa bakteriofag litik LB1 dapat mengurangi populasi sel Salmonella sebanyak 67,12\% setelah 8 jam inkubasi. Bakteriofag litik LB1 memiliki 8 protein yang berbeda dengan berat molekul yang beragam 11,4 kDa; 19,6 kDa; $23 \mathrm{kDa} ; 33 \mathrm{kDa} ; 58,3 \mathrm{kDa} ; 77 \mathrm{kDa} ; 94.5 \mathrm{kDa} ; 133 \mathrm{kDa}$. Studi ini menunjukkan bahwa bakteriofag litik LB1 yang diisolasi pembuangan limbah domestik dapat secara efektif mengurangi Salmonella enterica dengan cara melisis sel bakteri. Bakteriofag litik LB1 berpeluang dapat digunakan sebagai biokontrol penyakit gastroenteritis yang disebabkan oleh Salmonella enterica. Stabilitas terbaik bakteriofag litik LB1 pada penyimpanan dalam buffer Ringer di suhu dingin $\left(4^{\circ} \mathrm{C}\right)$, memiliki karakterisasi famili
\end{abstract}


Siphoviridae, dapat mengurangi Salmonella enterica sebanyak 67.12\% setelah 8 jam inkubasi, dan memiliki berat molekul 11,4-133 kDa.

Kata kunci: bakteriofag litik, gastroenteritis, Salmonella.

\begin{abstract}
Salmonella enterica is one of pathogenic bacteria causing gastroenteritis transmitted by water and food contamination which commonly occur in developing country. Some study reported that Salmonella serovar enterica strains were multi-resistant to various of antibiotics. Lytic bacteriophage in Siphoviridae family offered a good solution to reduce gastroenterytis disease caused by Salmonella enterica. This reseach aim was to isolate, effectivity test of LB 1 and to characterize lytic bacteriophage as biocontrol of gastroenterytis. Methodology and results were LB1 lytic bacteriophage was isolated from domestic waste using double layer plaque technique, was determined by the plaque morphology, the structure, the host range, the activity to lyse bacterial host cells, the stability of phage on different buffer conditions, and the protein characterization. The results showed that LB1 only infects Salmonella enterica. Based on Electron Microscope Observation showed that LB1 is grouped into Siphoviridae. It has hexagonal-icosahedral head with $72.7 \mathrm{~nm}$ in diameter and long-non contractile tail with $100 \mathrm{~nm}$ in diameter. LB1 had a good storage stability in Ringers buffer at low temperature $\left(4^{0} \mathrm{C}\right)$, with viability of bacteriophage decreased by $28 \%$ after 3 weeks of storage. The effectiveness showed that LB1 could reduce Salmonella enterica by $67.12 \%$ after 8 hours of incubation. LB 1 has different proteins with molecular weights: $11.4 \mathrm{kDa}, 19.6 \mathrm{kDa}, 23 \mathrm{kDa}, 33 \mathrm{kDa}, 58.3 \mathrm{kDa}, 77$ $\mathrm{kDa}, 94.5 \mathrm{kDa}$, and $133 \mathrm{kDa}$. The conclusion was LB1 was isolated from sewage water were identified to reduces Salmonella enterica effectively with concentration of $8.2 \times 10^{8} \mathrm{CFU} / \mathrm{mL}$. LB 1 can be used as a biocontrol of gastroenterytis caused by Salmonella enterica, LB 1 has the best stability in buffer ringers in cold temperatures $\left(4^{\circ} \mathrm{C}\right)$ and proven as Siphoviridae family, reduced Salmonella enterica by $67.12 \%$ after 8 hours of incubation, and has protein molecule with molecular weight 11.4 to $133 \mathrm{kDa}$.
\end{abstract}

Keyword: gastroentritis, lytic bacteriophage, Salmonella.

Penulis korespondensi :

Debi Arivo

Department of Microbiology, Medical Faculty of Malahayati Univercity,

$27^{\text {th }}$ Pramuka street, Bandar Lampung

Email :arivod@yahoo.com 


\section{INTRODUCTION}

Salmonella enterica is a bacterium that causes foodborne disease in humans, which is common throughout the world. Salmonellosis is a disease caused by Salmonella bacterial infection. Symptoms are characterized by diarrhea, fever, and pain in the abdomen (Mahamuni et al., 2017). If eggs are consumed raw or not cooked properly and consumed by humans, it can cause salmonellosis (Seockmo et al., 2016). Diarrhea and gastroenteritis are the first sequence diseases that cause hospitalization in hospitals in Indonesia with the number of cases of outbreaks of diarrhea in 2010 as many as 2,580 with deaths of 77 cases (CFR 2.98\%) (Kemenkes RI, 2014).

In case of severe Gastroenteritis, it uses antibiotics. Excessive use of antibiotics in addition to causing dangerous side effects can also risk the emergence of bacterial resistance to antibiotics (Odonkor and Addo, 2011). The previous studies report that some Salmonella isolated from raw chicken meat are resistant to ampicillin and tetracycline (CDC, 2015). Eng et al,. (2012) reported that some Salmonella showed resistant to ampicillin, chloramphenicol, and trimethoprim-sulfamethoxazole. Antibiotic resistance not only exposes pathogenic bacteria, but can also expose bacteria that act as normal flora, so we need a natural biocontrol.

Siphoviridae bacteriophages family is one alternative to control pathogen bacteria which were reported to infect pathogenic bacteria. The previous studies reported that Siphoviridae bacteriophage can reduces Klebsiella pneumonia cells causing outbreaks of nosocomial infections because of its ability to caused multidrugs-resistant (Jamal et al. 2015). It can reduces Salmonella serovar enterica isolated from fecal samples (Phothaowrn et al. 2019). Lytic bacteriophage are natural and non-toxic methods to reduce and control the growth of human pathogenic bacteria because bacteriophages are part of the gastrointestinal and environmental ecosystems (Bhardwaj et al. 2015). The presence of bacteriophages widespread in nature. Occupied environment by host bacteria is a source of existence various types of phage that can be isolated for variety aim (Shende et al. 2017). Therapy using lytic bacteriophages is more beneficial because the use is more profitable than antibiotics, bacteriophages only infect the target pathogen, so that the microflora normal in the intestine is not disturbed, second bacteriophages self-replicating in bacteria and completely destroys host bacterial cells through the lysis process kills host bacteria (Strydom and Witthuhn, 2015; Cheng et al., 2018; Harada et al., 2018), and specificity in attacking host target (Kittler et al., 2017; Harada et al., 2018; Santos et al., 2018).

Many studies have reported on the use of bacteriophages as a substitute for antibiotics to combat the growth of pathogenic bacteria, for example The Identification of Salmonella $\mathrm{sp}$ contamination and Isolation of Bakteriophage as Biocontrol in Handling Post Vannamei Shrimp Harvesting (Litopennaus vannamei) (Anjung, 2016). Saefunida et al. (2016) reported that lytic bacteriophage isolates were able to lyse E. coli by $92.1 \% \%$. Lytic bacteriophages have optimal growth in order to be able to lyse host cells, so that a suitable environment is needed so that lytic bacteriophages can infect host cells and replicate well (Pelzek, 2013). The existence of environmental factors such as temperature and buffer is thought to influence the damage to the structure of elements such as the head, tail, protein, and changes in the structure of DNA so that it affects the production of lytic bacteriophages. Research on lytic bacteriophages is still rarely done in Indonesia, so this research needs to be done to isolate, effectivity test, and characterize of lytic bacteriophage which can lyse Salmonella cells causing gastoenteritis. 


\section{METHOD}

The research was experimental laboratoric by using post test control group design. The population was Salmonella enterica. isolated from faecal of diarrhea patients in Bogor tested by $\mathrm{IMViC}$ test. The samples was sewage water taken from three different places.

\section{Research Instruments}

Nutrient Agar (Difco, Becton Dickinson and Company, USA), Nutrien Broth (Difco, Becton Dickinson and Company, USA), Salmonella Shigella Agar (SSA) (Oxoid CM009), Eosin Methylene Blue Agar (Oxoid, Basingstoke, UK), buffer ringers [ $8 \mathrm{~g} \mathrm{NaCl}, 0.42 \mathrm{~g} \mathrm{KCL}, 0.24 \mathrm{~g}$ $\mathrm{CaCl}_{2}, 0.20 \mathrm{~g} \mathrm{NaHCO}_{3}$ in 1 litre $\mathrm{H}_{2} \mathrm{O}$ ], buffer SM [5.8 g NaCl, $2 \mathrm{~g} \mathrm{MgSO} \cdot 7 \mathrm{H}_{2} \mathrm{O}, 50 \mathrm{~mL}$ Tris-Cl ( $\mathrm{pH}$ 7.5), $5 \mathrm{~mL}$ gelatine in 1 litre $\mathrm{H}_{2} \mathrm{O}$ ], pre-stained protein (Pageruler Prestained Protein Ladder, Thermo Scientific Fermentas Technology, UK), TEM (JEOL JEM-1010, Tokyo, Japan). The isolates used to determine the host range consisted of Escherichia coli,, Proteus mirabilis, Bacillus pumilus, and Photobacterium damselae obtained from the Bogor Culture Collection Agricultural Institute (IPBCC), Department of Biology, Bogor Institute of Agriculture.

\section{Research Flow}

\section{Isolation of Lytic Bacteriophage}

Sampling. The sample used was domestic waste from sewer water and septic tanks. Samples are taken and put in sterile bottles of 5-10 mL. Then the sample is homogenised and then filtration is carried out.

Filtration. A total of $1 \mathrm{~mL}$ of domestic waste sample was diluted into $9 \mathrm{~mL} \mathrm{NB}$ media, then centrifuged at 3,000 rpm for 20 minutes, and filtered using $0.45 \mu \mathrm{m}$ millipore membrane. The filtrate from the filter was $4.5 \mathrm{~mL}$ then mixed with $0.5 \mathrm{~mL}$ of Salmonella sp. OD600 culture $=1\left(10^{8} \mathrm{CFU} / \mathrm{mL}\right)$ and $5 \mathrm{ml}$ of Nutrient Broth (NB) was added. The mixture is incubated for 2448 hours in a Water Bath shaker at $37^{\circ} \mathrm{C}$. The culture was then centrifuged at $3000 \mathrm{rpm}$ at $4{ }^{\circ} \mathrm{C}$ for 15 minutes. Supernatant was taken with syringe and filtered using $0.22 \mu \mathrm{m}$ millipore membrane. The filtered supernatant is inserted into a sterile tube.

Double layer Plaque Technique. A total of $100 \mu \mathrm{L}$ of Salmonella sp. lytic bacteriophage stock was diluted into buffers with serial dilutions of $10^{-1}$ to $10^{-6}$. Each was taken as much as 100 $\mu \mathrm{L}$ and each was mixed with $100 \mu \mathrm{L}$ of Salmonella bacteria into a sterile effendorp tube and incubated at $37^{\circ} \mathrm{C}$ for 30 minutes. The mixture was added with $7 \mathrm{~mL}$ soft agar which had a temperature of $47^{\circ} \mathrm{C}$, poured on NA media. Incubation was carried out at $37^{\circ} \mathrm{C}$ for 24 hours and then plaque was formed (Jatmiko, dkk., 2018).

Bacteriophage purification. The plaque that is formed is taken using a pasteur pipette and enrichment is carried out so that the resulting plaque will increase. The plaque was transferred into $10 \mathrm{~mL}$ Salmonella sp. culture and incubated for 24 hours centrifuged at 3000 $\mathrm{rpm}$ at $4^{\circ} \mathrm{C}$ for 20 minutes, the bacteriophage filtrate was then filtered using a $0.22 \mu \mathrm{m}$ millipore membrane. The results of the filter in the form of bacteriophage filtrate then carried out on petri dish. The resulting plaque formed is then taken and put into the Ringers buffer. Suspension of bacteriophage were vortex and left for 5-10 minutes at room temperature, then centrifuged at a speed of $3000 \mathrm{rpm}$, a temperature of $4^{\circ} \mathrm{C}$ for 20 minutes for 2 replications. The supernatant was filtered using $0.22 \mu \mathrm{m}$ millipore filter membrane and then stored as bacteriophage stock (Merabishvili et al., 2009). 


\section{Production of Lytic Bacteriophage}

A total of $10 \mathrm{~mL}$ of Salmonella sp. bacterial culture on NB media was centrifuged at 3000 $\mathrm{rpm}$, at $4^{\circ} \mathrm{C}$ for 20 minutes. The pellets formed were each infected with $100 \mu \mathrm{L}$ of lytic bacteriophage. The mixture was incubated at $37^{\circ} \mathrm{C}$ for 30 minutes, then added $10 \mathrm{~mL}$ of NB media and incubated for 24 hours at $37^{\circ} \mathrm{C}$. Then the culture was centrifuged at a speed of 3000 rpm, temperature $4^{\circ} \mathrm{C}$ for 20 minutes. The supernatant formed was taken with a syringe and filtered with a $0.22 \mu \mathrm{m}$ membrane filter. Each filtered supernatant is put into a sterile tube and stored (Kropinski \& Lavigne, 2009).

\section{Lytic Bacteriophage Quantification}

Phage quantification is measured by calculating the number of plaque formed (Plague Forming unit/PFU per $\mathrm{mL}$ ). Lytic bacteriophage stock was diluted up to $10^{-8}$, then from each dilution of the bacteriophage isolate, $100 \mu \mathrm{L}$ was added with $100 \mu \mathrm{L}$ of Salmonella sp. bacterial culture that had been incubated for 24 hours on NB media. The suspension was incubated for 30 minutes at $37^{\circ} \mathrm{C}$. A total of $7 \mathrm{~mL}$ of soft so that the temperature $47^{\circ} \mathrm{C}$ was mixed, then each was poured into the NA media, incubated at $37^{\circ} \mathrm{C}$ for 24 hours. Then the formation of plaque (clear zone) is observed and the amount is calculated (Kropinsky \& Lavigne, 2009).

\section{Efectiveness of Cell Lysis by Lytic Bacteriophage}

The testing was by infecting $3.4 \times 10^{6} \mathrm{PFU} / \mathrm{mL}$ lytic bacteriophages with $3 \times 10^{5} \mathrm{CFU} / \mathrm{mL}$ Salmonella bacteria in NB media. Control is done by culturing Salmonella sp. bacteria into NB media without the addition of lytic bacteriophages. Each treatment and control were incubated at 0 hour, 2 hour, 4 hour, 6 hour, and 8 hour intervals, by Total Plate Count (TPC) using NA to count the number of live bacteria at each time interval.

\section{Effect of Buffer and Storage Temperature on The Stability of Salmonella Lytic Bacteriophages}

Salmonella lytic bacteriophage plaques are purified by removing plaque formed using a pasteur pipette. The plaque is then mixed with the Ringers buffer and the Saline Magnesium (SM) buffer. For control, Nutrient Broth (NB) is used. Each bacteriophage suspension was vortex and left for 5-10 minutes at room temperature, centrifuged at $3000 \mathrm{rpm}$ at $4^{\circ} \mathrm{C}$, filtered using a $0.22 \mu \mathrm{m}$ millipore membrane (Phumkhachorn \& Rattanachaikunsopon 2010). Then Double Layer Plaque Technique was performed to determine the concentration of lytic bacteriophages. Each bacteriophage filtrate was stored at room temperature $\left(25^{\circ} \mathrm{C}\right)$ and cold temperature $\left(4^{\circ} \mathrm{C}\right)$, the Double Layer Plaque Technique was assay on the third, sixth, and nineth, and counted the number of plaques formed in Salmonella Shigella Agar (SSA) (Phumkhachorn \& Rattanachaikunsopon, 2010).

\section{Determination of Specificity of Salmonella Lytic Bacteriophage}

Each of $100 \mu \mathrm{L}$ of Salmonella, Bacillus pumilus, Photobacterim damselae, and Proteus mirabilis cultures that had been grown in NB media in the exponential phase were each mixed with $100 \mu \mathrm{L}$ of Salmonella lytic bacteriophage stock. Then each incubated at $37^{\circ} \mathrm{C}$ for 30 minute. Each bacterium that had been mixed with Salmonella lytic bacteriophage was performed with a double layer plaque technique. Incubated at $37^{\circ} \mathrm{C}$ for 24 hours and see the formed plaque (Phumkhachorn \& Rattanachaikunsopon, 2010). 


\section{Morphological Observation of Lytic Phages by Transmission Electron Microscope (TEM)}

Lysed bacteria in Ringers buffer were dropped $5 \mu \mathrm{L}$ on the grid (400 mesh) using a micropipette, waited for 20 seconds, then dried with filter paper. A total of $5 \mu \mathrm{L}$ of acetyl acetate $2 \%$ was dropped onto the grid and waited for 1 minute. The grid is dried using filter paper and left for 20 minutes to dry completely. Electron Microscope grids are placed in the holder, left to dry. After the dry specimen is examined using a transmission electron microscope (JEOL JEM1010) with 10000x-100000x magnification (Carey et al., 2006).

\section{Molecular Weight Analysis of Salmonella Lytic Bacteriophage Protein}

Sodium Dodesyl Sulphate-Poly Acrilamide Gel Electrophoresis (SDS-PAGE) was used to determine the molecular weight of lytic bacteriophage proteins analyzed. The marker was the PageRegularTMPrestained Protein Ladder with molecular weights of 10, 17, 28, 34, 48, 55, 72, 95,130 , and $180 \mathrm{kDa}$ respectively. A gel separation of $12 \%$ polyacrylamide is placed at the bottom. The concentration of the collecting gel was $7.5 \%$ polyacrylamide which was placed at the top after the separating gel was solid. The phytic phages and markers are each mixed with a sample buffer at a ratio of 4: 1 (4 parts of sample and 1 part of sample buffer). The mixture was centrifuged at a speed of $1000 \mathrm{rpm}$, room temperature, for 20 minutes and heated in boiling water for 5 minutes, put into a gel well with a volume of $45 \mu \mathrm{L}$. Electrophoresis is run with a current of $20 \mathrm{~mA}$ and a voltage of 50 volts for 3.5 hours. Electrophoresis is terminated when the dye sample reaches the $0.5 \mathrm{~cm}$ to $1 \mathrm{~cm}$ limit from the bottom of the gel. After the electrophoresis ends, the gel is removed from the glass slab and done with silver stain staining (Bradford, 1976).

\section{RESULT}

\section{Isolation of Lytic Bacteriophage}

Isolation was carried out using domestic waste samples consisting of sewage water and septic tank water on Natar, Lampung Selatan.

Tabel I. Isolation of Lytic Bakteriophage on Salmonella

\begin{tabular}{cccccc}
\hline Jenis LCRT & $\begin{array}{c}\text { A number } \\
\text { of Sampel }\end{array}$ & $\begin{array}{c}\text { Bacteriophage } \\
\text { Isolation }\end{array}$ & $\begin{array}{c}\text { Bacteriophage } \\
\text { Type }\end{array}$ & $\begin{array}{c}\text { Plaque } \\
\text { Morphology }\end{array}$ & $\begin{array}{c}\text { Plaque Diameter } \\
\text { (mm) }\end{array}$ \\
\hline Sewer water 1 & 2 & + & LB1 & clear & 0,8 \\
$\begin{array}{c}\text { Sewer water 2 } \\
\text { Septic tank } \\
\text { water }\end{array}$ & 2 & - & - & - & - \\
\hline
\end{tabular}

Bacteriophages can only reproduce at the appropriate host. The presence of clear zones or plaques in Salmonella culture grown in petri dishes is an important parameter of the presence of bacteriophages in the lytic cycle. Bacterioag isolation results obtained 1 bacteriophage isolate and named LB1 (Figure 1). 


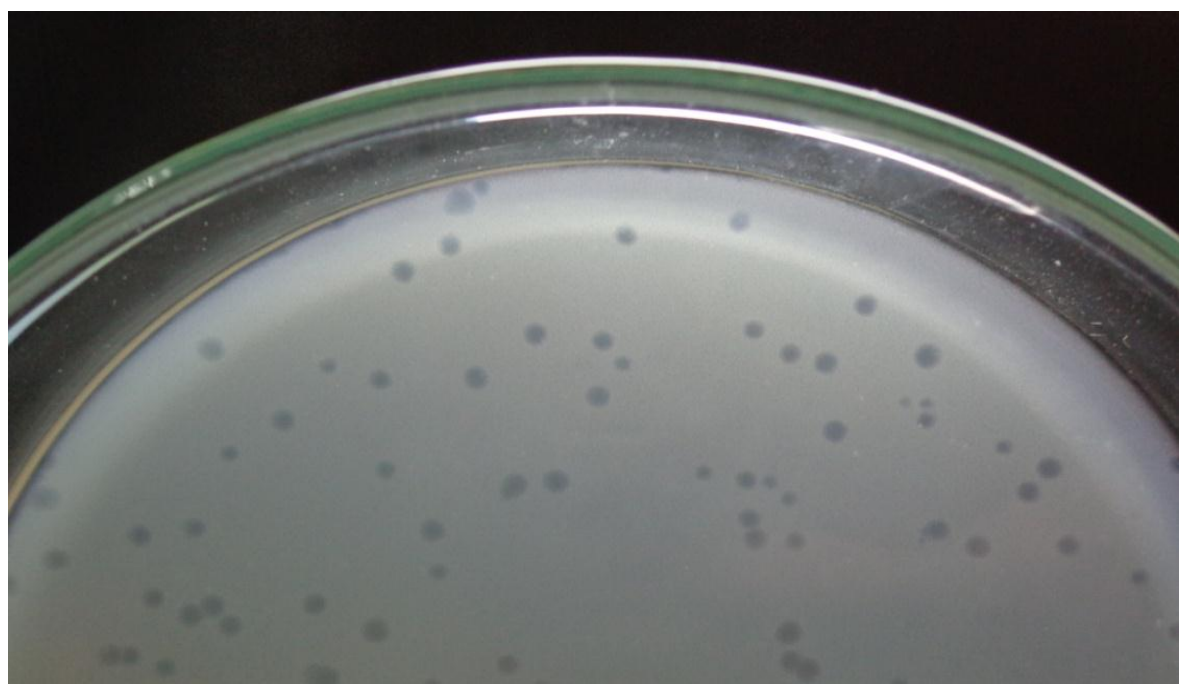

Figure 1. Pattern of LB1 bacteriophage plaque on Salmonella

\section{Quantification of Lytic Bacteriophage}

Purified lytic bacteria LB1 then the amount of concentration was calculated based on the amount of plaque formed. The amount of plaque formed is then calculated in units of Plaque Forming Unit (PFU/mL) (Table 2) which is a measure of the amount of infective fluid volume of the virus. In addition, the calculation of lytic bacteriophage concentration was calculated. LB1 is a lytic bacteriophage with a titer of $8.6 \times 10^{8} \mathrm{PFU} / \mathrm{mL}$, showed that LB1 lytic bacteriophages are effective in infecting Salmonella.

\section{Lytic Bacteriophage Lysis Effectiveness}

The effectiveness of Salmonella cell lysis by LB1 lytic bacteriophages carried out by counting bacterial cells directly, the number of bacteria is calculated using Standar Plate Count (SPC) (Figure 2).

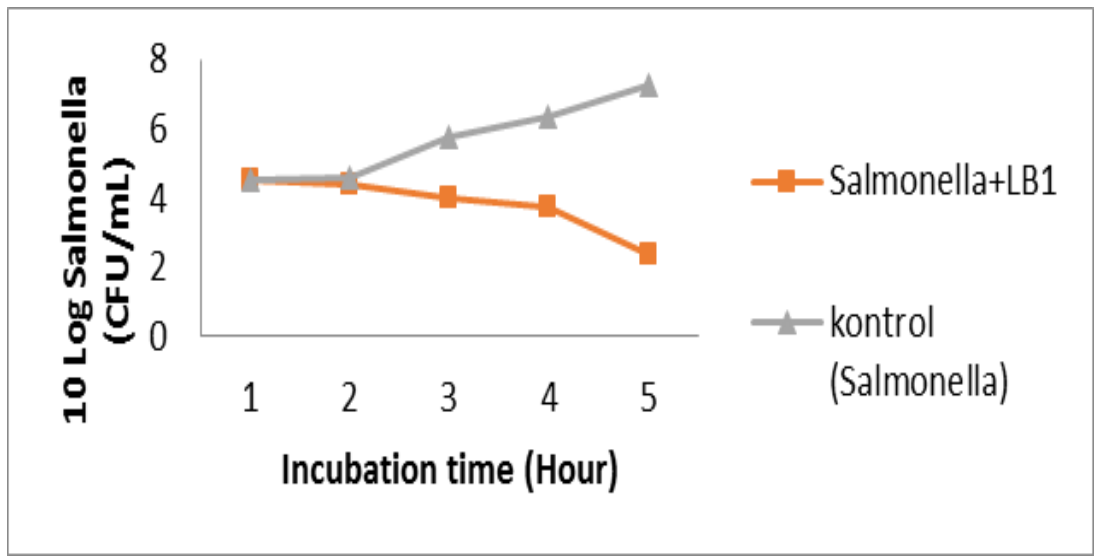


Figure 2. The effectiveness of Salmonella sp. cell lysis by bacteriophages. Salmonella sp. lysis by LB1 bacteriophage infected (匹), and control Salmonella sp. without bacteriophage infected $(\triangle)$.

\section{Host Specificity}

Determination of the range of lytic bacteriophage hosts is carried out to see the host specificity of the bacteriophages obtained. In determining the range of hosts, LB1 bacteriophages were tested against several other bacteria besides Salmonella sp., namely; Esherichia coli, Proteus mirabillis, Bacillus pumilus, and Photobacterium damselae (figure 4). Host range test results indicate that LB1 lytic bacteriophages have a narrow range of hosts or are host specific.
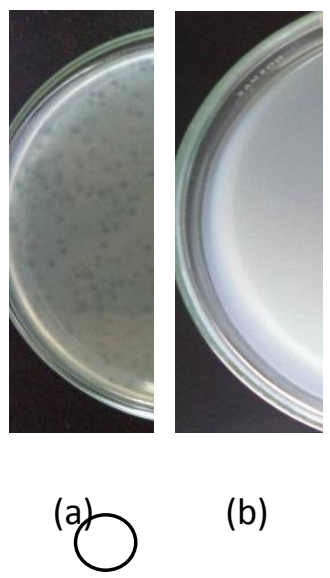

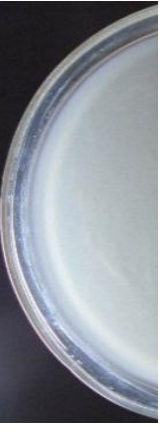

(c)

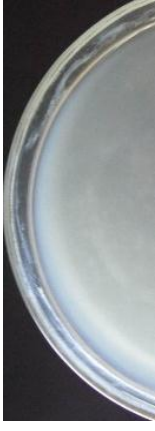

(d)

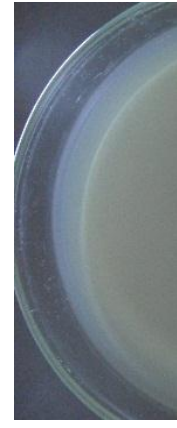

(e)

Figure 3. Plaque appears on bacteriophages that are infected with the Salmonella sp. (a), whereas bacteriophages which infected by E. coli (b), Proteus mirabilis (c), Bacilus pumilus (d), and Photobacterium damselae (e) did not showed plaque appearance. (O) showed lytic bacteriophage.

\section{Protein Characterization of Lytic Bacteriophage}

Protein levels in LB1 lytic bacteriophages are seen in Figure 4. However, the protein levels in LB1 lytic bacteriophages are relatively small compared to levels of lytic bacteriophage protein in general (protein concentration $158 \mu \mathrm{g} / \mathrm{mL}$ ). SDS-PAGE results which were given silver nitrate showed that LB1 lytic bacteriophage suspension contained protein with molecular weights of $11.4 \mathrm{kDa}, 19.6 \mathrm{kDa}, 23 \mathrm{kDa}, 33 \mathrm{kDa}, 58.3 \mathrm{kDa}, 77 \mathrm{kDa}, 94 \mathrm{kDa}$, and $133 \mathrm{kDa}$ respectively. Protein band formed on LB1 lytic bacteriophage can indicate the LB1 bacteriophage lytic protein. 


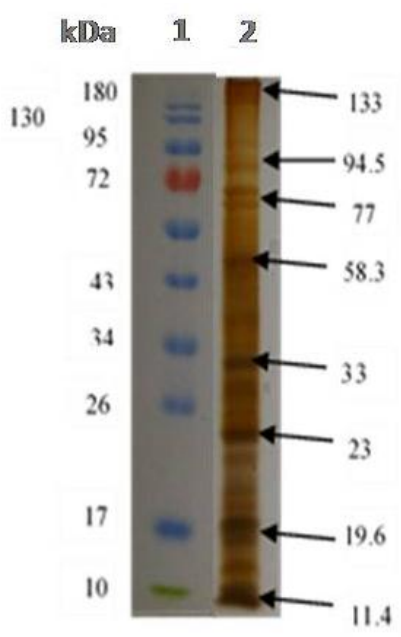

Figure 4. Lytic bacteriophage protein profile with SDS-PAGE; marker (1), and LB1 lytic bacteriophage (2).

\section{Morphological Observation Results of Lytic Phages with Transmission Electron Microscope (TEM)}

Morphological analysis of lytic bacteriophages was performed using the Transmission Electron Microscope JEOL JEM-1010 with a negative staining of uranyl acetate 2\%. Lytic bacteriophage observations were carried out using a magnification of 60000x (Figure 5). Lytic bacteriophage LB1 has a hexagonal hexagonal head with a diameter of $72.7 \mathrm{~nm}$, has no contractile sheath, a tail length of $100 \mathrm{~nm}$ and a diameter of $18.2 \mathrm{~nm}$. LB1 bacteria are included in the Siphoviridae family.

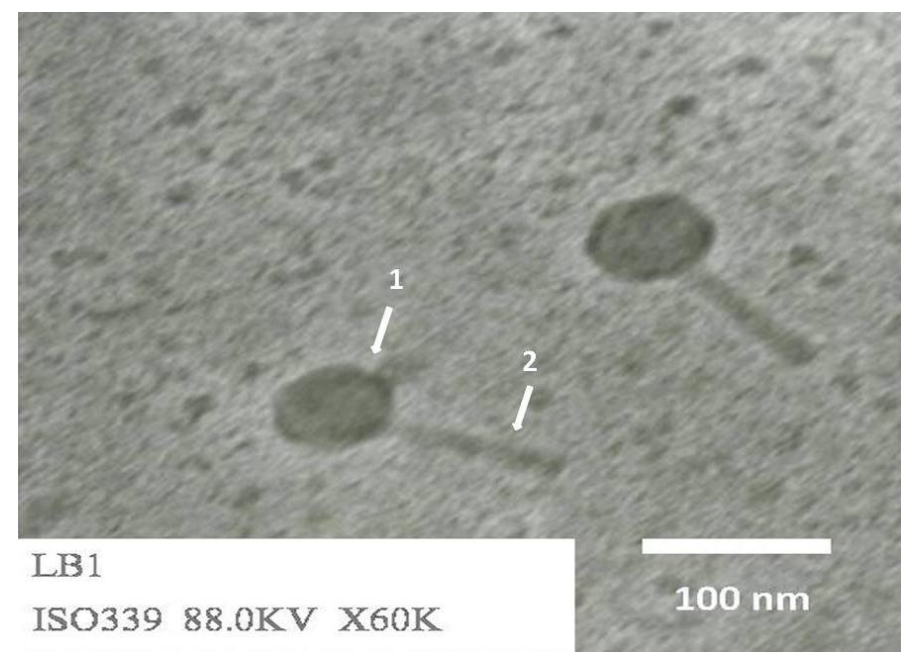

Figure 5. LB 1 lytic bacteriophage by magnification of 60000x; head (1), tail (2). 


\section{Effect of buffer and storage temperature on the stability of LB1 lytic bacteriophage}

The LB1 lytic bacteriophage stability test is carried out by storing bacteriophages in the buffer which aims to find out the best buffer for LB1 lytic bacteriophage storage. Bacteriophage storage treatment uses 2 types of buffer, namely: buffer Ringers and Saline Magnesium (SM) buffer with two different storage temperatures, namely: room temperature $\left(27^{\circ} \mathrm{C}\right)$ and cold temperature $\left(4^{\circ} \mathrm{C}\right)$. Bacteriophage storage in NB is used as a control. The best bacteriophage LB1 stability is found in bacteriophages stored in Ringers buffer at cold temperature $\left(4^{\circ} \mathrm{C}\right)$ (Figure 6).

(a)

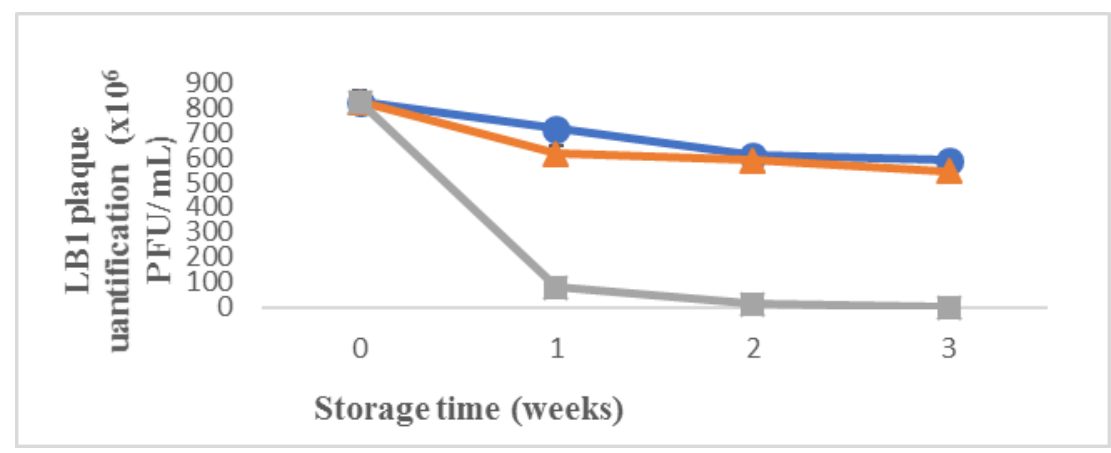

(b)

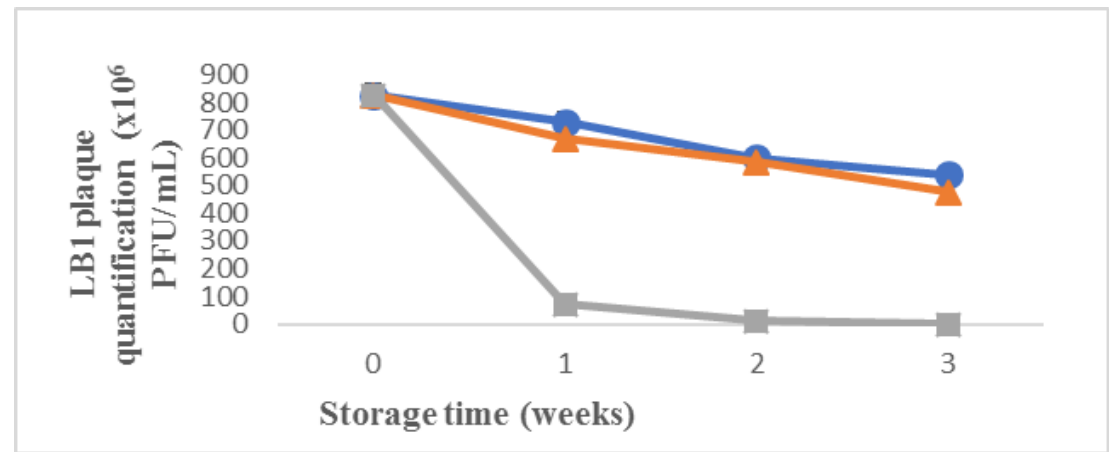

Figure 6. $\mathrm{LB} 1$ lytic bacteriophage stability in cold temperature $4^{\circ} \mathrm{C}$ (a), and room temperature $25^{\circ} \mathrm{C}(\mathrm{b})$. Each incubated in Ringers buffer ( $\bullet$ ), SM buffer ( $\Delta$ ), and NB as control ( $\square$ ).

LB1 lytic bacteriophage showed the best stability in storing ringers buffer at cold temperatures $\left(4^{\circ} \mathrm{C}\right)$, this can be seen from the reduction in plaque amount by $28 \%$ after 3 weeks of storage, whereas at room temperature $\left(27^{\circ} \mathrm{C}\right)$ plaque decreased by $33.9 \%$ after 3 weeks of storage. LB1 lytic bacteriophages stored in the SM buffer at $4^{\circ} \mathrm{C}$ and $27^{\circ} \mathrm{C}$ experienced greater plaque reduction, namely: $33.3 \%$ and $42.4 \%$ after 3 weeks of storage. Lytic bacteria LB1 stored in NB medium as a control at $4^{\circ} \mathrm{C}$ and $27^{\circ} \mathrm{C}$ did not have plaque at the third week of storage.

\section{DISCUSSION}

Phage has a specific bacterial target so that there are no adverse effects on bacteria as microflora, does not cause side effects in humans, storage is relatively stable in different environmental conditions so that production costs are cheap (Hagens and Loessner, 2010). Plaque quantification showed that LB1 has a titer of $8.6 \times 10^{8} \mathrm{CFU} / \mathrm{mL}$. LB1 bacteriophage was 
able to infect Salmonella enterica well at 8 hours incubation time. The more bacteriophages produced, the more bacterial cells are lysed by bacteriophages. This allows the opportunity for LB1 to be applied in biocontrol of water and food poisoning. Compared to Jatmiko (2018) hihgest density bacteriophage was $\mathrm{S} 2-\mathrm{St}\left(1,20 \times 10^{10} \mathrm{PFU} / \mathrm{mL}\right)$ but the best reduce of Salmonella typhi was B2-St with significant value at the 4th hour, wich showed that B2-St was the best fage even though it has lower density, thought to be due to the type of virus which infects differently, so it has the different ability to infect, replicate and lyses the bacteria, although the bacteriophage cannot lyse bacteria in a manner whole. Plaque size is also influenced by several factors, such as agar concentration, incubation conditions, and the log phase of host bacteria (Kropinski and Lavigne, 2009).

The appearance of plaque indicates that LB1 bacteriophages most of the phages only infect one serotype in one bacterial species. The results of the study of Strydom and Witthuhn (2015), Cheng et al., (2018) and Harada et al., (2018) showed bacteriophages only infect the target pathogen, and specifically attacking host target (Kittler et al., 2017; Harada et al., 2018; Santos et al., 2018). The LB1 host specificity suggests that the surface of Salmonella bacterial cells has receptors that are specific to LB1 phytic phlegm that are not possessed by other bacteria. Phage attaches to cells that are sensitive to stimulation at specific locations in the bacterial cell wall bakteri (Rakhuba et al., 2010). Study of Jatmiko (2018) reported that B2St, B3St, S1St, S2St, SL1St, SL3St could lyse Salmonella typhimurium and E. coli with the formed of plaque, this likely related to similarity in host receptor molecules (Silva et al., 2016) and Deshanda et al., (2018) showed F1, F2, H1, H3, E1, E2 fag could lyse Salmonella, E. coli and Staphylococcus aureus, while fag F2 lyse Salmonella and Staphylococcus aureus only. It means 6 from 7 fag types had larger host range. LB1 bacteria are included in the Siphoviridae family, compared to Hardanti et al., (2018) KAS phages have morphological characteristics of Podoviridae family with cubic symmetry shaped head and unclear short tail. The effectiveness of lytic bacteriophages in bacterial lysis test aims to determine the exact time needed by bacteriophages to control the proliferation of host bacteria.

The effectiveness of bacteriophage test is done because Salmonella is a common bacterium that causes diarrheal disease after EPEC, so the effectiveness of lytic bacteriophages is expected to be able to control the growth of Salmonella. Several physical and chemical factors such as temperature and ion determine the resistance of bacteriophages. Improper storage will cause damage to the structure of the head, tail, and changes in the structure of DNA (Jonczyk et $a l ., 2012)$. The stability of LB1 lytic bacteriophages is best in bacteriophages stored in Ringers buffer at cold temperatures $\left(4^{\circ} \mathrm{C}\right)$, this can be seen from the reduction in plaque amount by $28 . \%$ after storage for 3 weeks The reduction in the amount of bacteriophage plaque stored in the Ringers buffer at cold temperatures $\left(4^{\circ} \mathrm{C}\right)$ has a relatively smaller reduction compared to the storage of bacteriophages in the SM buffer. This is because the presence of $\mathrm{Ca}^{2+}$ and $\mathrm{Mg}^{2+}$ ions contained in the Ringers buffer can simultaneously increase the number of bacteriophage plaques caused by these multivalent ions can increase the efficiency of phage adsorption into host cells (Cele, 2009).

Capsic and tail of lytic bacteriophage consists of protein. The constituent proteins vary and have different functions. These functions include the protection of bacteriophages against their resistance in the environment and play a role in the process of replication to cause lysis of host cells. The protein possessed by LB1 lytic bacteriophages tends to be small in every milliliter. LB1 has a protein concentration of $158 \mu \mathrm{g} / \mathrm{mL}$. Through SDS-PAGE we can find 
variations of protein molecular weight in lytic bacteriophages. The variation in protein molecular weight indicates the proteins that make up lytic bacteriophages.

\section{CONCLUSSION}

LB1 was isolated from sewage water were identified to reduces Salmonella enterica effectively with concentration of $8.2 \times 10^{8} \mathrm{CFU} / \mathrm{mL}$. LB 1 can be used as a biocontrol of gastroenterytis caused by Salmonella enterica, LB 1 has the best stability in buffer ringers in cold temperatures $\left(4^{\circ} \mathrm{C}\right)$ and proven as Siphoviridae family, reduced Salmonella enterica by $67.12 \%$ after 8 hours of incubation, and has protein molecules with molecular weight 11.4 to 133 $\mathrm{kDa}$.

\section{ACKNOWLEDGEMENT}

This reseach was supported by Directorate General of Higher Education, Ministry of National Education, Indonesia through novice lecturer reseach program. We thank Mrs. Dewi Asnita for helping this reseach.

\section{REFFERENCE}

Anjung, M.U.K. 2016. Identifikasi cemaran Salmonella sp dan isolasi bakteriofage sebagai biokontrol dalam penanganan pasca panen udang vannamei (Litopennaus vannamei). Disertasi. Universitas Lampung. Bandar Lampung.

Bhardwaj, N., Bhardwaj, S.K., Deep, A., Dahiya, S., and Kapoor, S. 2015. Lytic Bacteriophages as biocontrol agents of foodborne pathogens. Asian Journal of Animal And Veterinary Advances 10(11): 708-723.

Bradford, M.M. 1976. A rapid and sensitive method for the quantitation of microgram quantities of protein utilizing the principle of protein-dye binding. Analytical Biochemistry 72(12): 248-254.

Carey-Smith, G.V., Billington, C., Cornelius, A.J., Hudson, J.A., and Heinemann, J.A. 2006. Isolation and characterization of bacteriophages infecting Salmonella spp. FEMS Microbiology Letters 258(2): 182-18.

Cele, N. 2009. Strategies to control bacteriophage infection in a threonine bioprocess. Dissertation of Master of Technology: Biotechnology. Durban University of Technology. Durban.

Centers for Disease Control and Prevention [CDC]. 2015. Salmonella enteritidis infection linked to raw, frozen, stuffed chicken entrees. http://www.cdc.gov/salmonella/frozen-chickenentrees-part2-07-15/index.html.

Cheng, J.H., Yang, H., Liu, M.L., Su, W., Feng, P.M., Ding, H., et al. 2018. Prediction of bacteriophage proteins located in the host cell using hybrid features. Chemometrics and Intelligent Laboratory Systems 180: 64-69. 
Deshanda R.P., Lingga R., Hidayati N.A., Sari E., Hertati R. 2018. Fag Salmonella asal limbah pasar ikan dan air sungai di sekitar Kampus Universitas Bangka Belitung. Ekotonia: Jurnal Penelitian Biologi, Botani, Zoologi Dan Mikrobiologi 3(2): 45-49.

Eng, S.K., Pusparajah, P., Ab Mutalib, N.S., Ser, H.L., Chan, K.G. and Lee, L.H. 2015. Salmonella: a review on pathogenesis, epidemiology and antibiotic resistance. Frontiers in Life Science 8(3): 284-293.

Hagens, S., and Loessner, M.J. 2010. Bacteriophage for biocontrol of foodborne pathogens: calculations and considerations. Current Pharmaceutical Biotechnology 11(1): 58-68.

Harada, L.K., Silva, E.C., Campos, W.F., Del Fiol, F.S., Vila, M., Dabrowska, K., et al. 2018. Biotechnological applications of bacteriophages: state of the art. Microbiological Research 212-213: 38-58.

Hardanti S., Wardani A.K., Putri W.D.R. 2018. Isolasi dan karakterisasi bakteriofag spesifik Salmonella typhi dari kulit ayam. Jurnal Teknologi Pertanian 19(2).

Jamal, M., Hussain, T., Das, C.R., and Andleeb, S. 2015. Characterization of Siphoviridae phage $\mathrm{z}$ and studying it efficacy against multidrug-resistant planktonic cells and biofilm. Journal of Medical Microbiology 64: 454-462.

Jatmiko Y. D., Purwanto A.P., Ardyati T. 2018. Uji aktivitas bakteriofage litik dari limbah rumah tangga terhadap Salmonella typhi. Jurnal Biodjati 3(2).

Jończyk, E., Kłak, M., Międzybrodzki, R., and Górski, A. 2011. The influence of external factors on bacteriophages. Folia Microbiologica 56(3): 191-200.

Kementerian Kesehatan Republik Indonesia. 2014. Situasi diare di Indonesia. Buletin Jendela Data dan Informasi Kesehatan. ISSN 2088-270x.

Kittler, S., Wittmann, J., Mengden, R.A.L.P., Klein, G., Rohde, C., and Lehnherr, H. 2017. The use of bacteriophages as one health approach to reduce multidrug resistant bacteria. Sustainable Chemistry And Pharmacy 5: 80-83.

Kropinski, A.M., and Lavigne, R. 2009. Bacteriophages. M.R. Clokie (Ed.). Vol 1. Humana Press. India.

Mahamuni, P.P., Patil, A.R., and Ghosh, J.S. 2017. Proteolytic and lipolytic properties of endotoxins (enterotoxins) produced by Salmonella typhi NCIM 5255, Salmonella typhimurium NCIM 2501 and Shigella exneri NCIM 5265. Internatonal Food Research Journal 24(6): 2685-2688. 
Merabishvili, M., Pirnay, J.P., Verbeken, G., Chanishvili, N., Tediashvili, M., Lashkhi, N., et al. 2009. Quality-controlled small-scale production of a well-defined bacteriophage cocktail for use in human clinical trials. PloS One 4(3): e4944.

Odonkor, S.T., and Addo, K.K. 2011. Bacteria resistance to antibiotics: recent trends and challenges. Int J Biol Med Res 2(4): 1204-10.

Pelzek, A.J. 2013. Isolation of Bacteriophages from Environmental Sources, and Creation and Functional Screening of Phage DNA Libraries. Current Protocols in Essential Laboratory Techniques 7(1): 13.3.1-13.3.35.

Phothaworn, P., Dunne, M., Supokaivanich, R., Ong, C., Lim, J., Taharnklaew, R., et al. 2019. Characterization of flagellotropic, Chi-like Salmonella phage isolated from Thai Poultry Farm. Viruses 11 (520): 10-17.

Phumkhachorn, P., and Rattanachaikunsopon, P. 2010. Isolation and partial characterization of a bacteriophage infecting the shrimp pathogen Vibrio harveyi.Afr. J. Microbiol. Res 4(16): 1794-1800.

Rakhuba, D.V., Kolomiets, E.I., Dey, E.S., and Novik, G.I. 2010. Bacteriophage receptors, mechanisms of phage adsorption and penetration into host cell. Pol. J. Microbiol 59(3): 145-155.

Saefunida D.M., Wjanarka, Rukmi M.D.I., Hidayat N.N. 2016. Isolasi bakteriofag Escherichia coli dari sistem distribusi air minum isi ulang sebagai antibiofilm. Jurnal Biologi 5(2).68-75.

Santos, S.B., Costa, A.R., Carvalho, C., Nóbrega, F.L., Azeredo, J. 2018. Exploiting bacteriophage proteomes: the hidden biotechnological potential. Trends in Biotechnology 36(9): 966-984.

Seockmo, K., Eduardo, X., Thomas, K., and Michael, R.L. 2016. Salmonella in shell eggs: mechanisms, prevention and detection. J Nutr Food Sci 6(1): 1-7.

Shende, R.K., Hirpurkar, S.D., Sannat, C., Rawat, N., Pandey, V. 2017. Isolation and characterization of bacteriophages with lytic activity against common bacterial pathogens. Veterinary World 10(8): 973-978.

Silva, J.B., Storms, Z., and Sauvageau, D. 2016. Host receptors for bacteriophage adsorption. FEMS Microbiology Letters 363(4): 1-11.

Strydom, A., and Witthuhn, C.R. 2015. Listeria monocytogenes: a target for bacteriophage biocontrol. Comprehensive Reviews In Food Science And Food Safety 14(6): 694-704. 